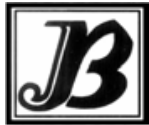

J. bio-sci. 16: 85-88, 2008

ISSN 1023-8654

http://www.banglajol.info/index.php/JBS/index

\title{
VARIABILITY AND INTERRELATIONSHIP AMONG YIELD AND YIELD CONTRIBUTING CHARACTERS IN ONION (ALLIUM CEPA L.)
}

\author{
M S Hossain, M Khalekuzzaman,, M H Rashid ${ }^{1}$ and M S Rahman \\ Department of Genetic Engineering and Biotechnology, University of Rajshahi, Rajshahi-6205, Bangladesh. \\ ${ }^{1}$ Institute of Biological Sciences, University of Rajshahi, Rajshahi-6205, Bangladesh.
}

\begin{abstract}
A study was conducted using seven varieties of onion (Allium cepa L.) and observations were recorded on yield and yield components in order to obtain informations on genetic variability and character association of onion. Higher genotypic coefficients of variations were recorded in number of seeds per scape (NSPS), final plant height (FPH), final scape height, fresh weight of bulb and bulb length. These characters also exhibited high heritability along with high genetic advance as percentage of mean. Phenotypic correlation coefficients showed that bulb length, bulb diameter and scape diameter were positively and significantly correlated with fresh weight of bulb. The number of seeds per scape, final scape height, final plant height and number of pseudostem branches at maximum flowering stage were also positively and significantly correlated with seed yield per scape.
\end{abstract}

Key words: Genetic variations, correlation, yield components, onion.

\section{Introduction}

Onion is one of the oldest cultivated plant species in the world among the bulbs. It is the most common and important crops among the vegetables and species in Bangladesh. It is used in almost all food preparations and is an integral part of Bangladesh diet (Hossain and Islam 1994). It is also used as delicious vegetable and salad in many countries of the world. On the account of its special characteristics of pungency, it is valued much. Onion is an important spice because of its excellent flavour, which increase the test of various types of foods and carries. Nutritionally, its bulb is rich in minerals and other nutrients, like calcium, protein, carbohydrate, vitamin C and iron and it also contains vitamin B in trace amount (Sharfuddin and Siddique 1985). Nadkarni (1927) reported various medicinal properties of onion. The juice of onion is used for treating opthalmia and earache. Bulb juice is used as smelling on hysterical fits in faintness and it is also used against flatulence, dysentery and cholera, heart disease. It plays an important role in reducing the insulin requirement for diabetic patient by regular use. Inspite of its various uses, very little research work has been under taken for its improvement in Bangladesh. Therefore, the present research work was undertaken to study the genetic and nongenetic variability and nature of interrelationship among yield and other yield contributing characters, which will be helpful in future breeding programme for the improvement of this crop.

\section{Materials and Methods}

A total of seven onion varieties, viz., Taherpuri brown, Taherpuri white, Pusa red, Pusa white, Patnaideep pink, Shitlai brown and Shamrat collected from Bangladesh Agricultural Research Institute, Joydebpur Gazipur were used in this study. The bulbs of the variety were used as the planting materials. The experiment was laid out in Randomized Complete Block Design with three replications at the experimental field of Academic Unit, Faculty of Agriculture, University of Rajshahi, Bangladesh during November, 2005 to April, 2006. The unit plot size was $3 \mathrm{~m} \times 1 \mathrm{~m}$ having $35 \mathrm{~cm}$ distance from row to row, $45 \mathrm{~cm}$ distance from plot

${ }^{*}$ Corresponding author 
to plot and $50 \mathrm{~cm}$ distance from replication to replication. The medium sized mother bulbs were planted in each row of the plots on $17^{\text {th }}$ November, 2005. Manure and fertilizers were applied at the rate of cowdung 0.5 tone, Urea $120 \mathrm{~kg}$, TSP $130 \mathrm{~kg}$ and MP $160 \mathrm{~kg} / \mathrm{ha}$. The entire amount of cowdung, TSP, MP and 50\% of Urea were applied at final land preparation. The rest 50\% Urea was applied as top dressed after 40 days of planting the bulbs. Normal cultural practices were followed as routine procedure to ensure normal growth of plants. Data on days to flower initiation (DFI) was recorded as plot basis, while other various characters viz., number of leaves at maximum flowering stage (NLMFS), number of pseudostem branches at maximum flowering stage (NPMFS), final plant height (FPH) in $\mathrm{cm}$, final scape height (FSH) in $\mathrm{cm}$, number of flowers per scape (NFPS), number of scape per plant (NSPP), number of seeds per scape (NSPS), scape diameter (SD) in $\mathrm{cm}$, fresh weight of bulb (FWB) in gm, bulb length (BL) in $\mathrm{cm}$, bulb diameter (BD) in $\mathrm{cm}$ and seed yield per scape (SYPS) in $\mathrm{mg}$ were recorded from randomly selected 10 sample plants from each plot. Phenotypic and genotypic variances were estimated by using the formula given by Johnson et al. (1955). Phenotypic and genotypic coefficient of variability was estimated according to the formula given by Burton (1952). Heritability in broad sense was estimated according to Hanson et al. (1956). The genetic advance as percentage of mean and phenotypic correlation coefficients was computed using the formula suggested by Comstock and Robinson (1952) and Al-Jibouri et al. (1958) respectively.

\section{Results and Discussion}

Variability and Genetic parameters: Analysis of variance for all the characters under study displayed significant variations among the varieties (Table 1). Variability of a character is measured by range and genotypic coefficient of variation (GCV). In most of the cases, considerable differences between phenotypic and genotypic coefficients of variations were observed (Table 2), which indicated that environment had influenced to a certain extent in the expression of most of the characters, except FSH, FWB and BL, suggesting these characters are less influenced by environment and genetic variation existed in the expression of these characters and this genetic variability can be exploited by selection (Burton and de Vane 1953).

Table 1. Analysis of variance, range, mean with standard error and coefficient of variation of yield and yield contributing characters in onion.

\begin{tabular}{ccccccccccccccc}
\hline SV & df & DFI & NLMFS & NPMFS & NSPP & NFPS & FPH & FSH & NSPS & SD & FWB & BL & BD & SYPS \\
\hline R & 2 & 1.91 & 5.98 & 1.02 & 0.098 & 1359.88 & 92.50 & 11.41 & 4830.81 & 0.08 & 1.48 & 0.09 & 0.90 & 0.13 \\
V & 6 & $132.13^{* *}$ & $207.86^{* *}$ & $7.40^{* *}$ & $1.23^{* *}$ & $3961.87^{* *}$ & $256.80^{* *}$ & $208.38^{* *}$ & $19621.75^{* *}$ & $0.23^{*}$ & $105.82^{* *}$ & $1.55^{* *}$ & $0.41^{* *}$ & $0.48^{*}$ \\
$\mathrm{E}$ & 12 & 17.39 & 31.23 & 0.43 & 0.202 & 844.03 & 31.64 & 31.04 & 2513.08 & 0.06 & 0.43 & 0.09 & 0.07 & 0.09 \\
\hline Range & - & 47.33 & 20.33 & 2.13 & 3.70 & 212.18 & 14.60 & 35.19 & 110.93 & 0.77 & 13.24 & 2.81 & 2.63 & 0.35 \\
& & -71.67 & -48.67 & -8.87 & -5.00 & -237.54 & -58.20 & -63.83 & -179.57 & -1.15 & -16.98 & -3.31 & -3.16 & -0.89 \\
\hline Mean & - & 58.55 & 32.47 & 4.33 & 4.71 & 245.14 & 42.37 & 46.93 & 151.93 & 0.96 & 15.15 & 3.11 & 2.93 & 0.73 \\
\pm SE & \pm 1.15 & \pm 1.67 & \pm 0.32 & \pm 0.25 & \pm 4.48 & \pm 1.61 & \pm 1.61 & \pm 5.25 & \pm 0.19 & \pm 0.35 & \pm 0.26 & \pm 0.19 & \pm 0.17 \\
\hline CV\% & - & 5.51 & 12.89 & 15.25 & 9.59 & 9.82 & 6.78 & 6.99 & 22.37 & 20.89 & 4.23 & 8.95 & 10.51 & 24.65 \\
\hline
\end{tabular}

$\mathrm{SV}=$ source of variation, $\mathrm{df}=$ degree of freedom, $\mathrm{R}=$ replication, $\mathrm{V}=$ variety, $\mathrm{E}=$ error and $\mathrm{CV} \%=$ coefficient of variation

As genetic coefficient of variation does not indicate the amount of heritable variation. Heretability estimates in broad sense were used for the determination of the proportion of the total genetic variation. The heritability estimates was high for BL (84.48\%), FSH (79.73\%), FWB (79.20\%), FPH (70.79\%) and NSPS (70.41\%), and SD exhibited lowest estimates of heritability $(50.00 \%)$ (Table 2). Genetic advance as percentage of mean was maximum for SD followed by FWB and NSPS. The rest of the characters also showed high values of genetic advance as percentage of mean. The heritability estimates though provide the basis for selection on phenotypic performance, Johnson et al. (1955) suggested that heritability estimates and expected genetic 
advance should always be considered jointly. The characters which have high heritability as well as high genetic advance are BL, FWB, FSH, FPH and NSPS indicating these are simply inherited characters, even if they are under ploygenic control and these characters could be improved through selection. Sandhu and Korla (1976) reported similar results in onion. Moderate heritability coupled with high genetic advance were found for DFI, NLMFS, NPMFS, NSPP and BD indicated that these characters were moderately heritable and both additive and nonadditive genes were involved to control these characters. Sandhu and Korla (1976) observed such additive and non-additive gene effects in onion. On the other hand, low heritability estimates along with high genetic advance for SD, SYPS, NFPS suggested that genotype-environment interaction play a significant role in the expression of these characters.

Correlation coefficients: Correlation coefficient estimation was done at phenotypic level for all 13 characters studied and the results obtained are shown in Table 3 . The results of the correlation coefficients revealed that most of the characters were positively related with each other. Correlation coefficients of NLMFS with NPMFS; NPMFS with SYPS; FPH with NSPP and SYPS; FSH with NFPS and SYPS; NFPS with NSPS; SD with fresh WB, BL and BD; NSPP with NSPS and SYPS; NSPS with SYPS; FWB with BL and BD, and BL with $\mathrm{BD}$ were found to be highly significant and positive, which indicate that these characters were strongly and directly associated with each other. Sandhu and Korla (1976) obtained similar results in onion. Negative and significant correlation between DFI with FSH and BD; SD with NSPP, NSPS; NSPP with BL, and FWB with SYPS. Significant and negative correlation between FWB and SYPS indicate that bulb yield per plant may be decreased with increase of this character.

Table 2. Components of variance and genetic parameters of yield and yield contributing characters in onion.

\begin{tabular}{|c|c|c|c|c|c|c|}
\hline Characters & $\sigma^{2} p$ & $\sigma^{2} g$ & PCV (\%) & GCV (\%) & $h_{b}^{2}(\%)$ & GA\% \\
\hline DFI & 55.64 & 38.25 & 95.03 & 65.33 & 68.75 & 18.04 \\
\hline NLMFS & 90.10 & 58.88 & 277.49 & 181.33 & 65.35 & 39.35 \\
\hline NPMFS & 3.42 & 2.11 & 78.98 & 48.73 & 61.70 & 54.28 \\
\hline NSPP & 0.55 & 0.34 & 11.68 & 7.22 & 61.82 & 20.05 \\
\hline NFPS & 1883.32 & 1039.28 & 768.26 & 423.95 & 55.18 & 20.12 \\
\hline FPH & 106.30 & 75.25 & 250.89 & 177.60 & 70.79 & 35.48 \\
\hline FSH & 74.15 & 59.12 & 158.00 & 125.97 & 79.73 & 30.14 \\
\hline NSPS & 8215.97 & 5784.86 & 5407.73 & 3807.58 & 70.41 & 86.53 \\
\hline SD & 0.78 & 0.39 & 81.25 & 40.63 & 50.00 & 94.76 \\
\hline FWB & 68.90 & 54.57 & 454.78 & 360.19 & 79.20 & 89.39 \\
\hline $\mathrm{BL}$ & 0.58 & 0.49 & 18.65 & 15.76 & 84.48 & 42.62 \\
\hline $\mathrm{BD}$ & 0.18 & 0.11 & 6.14 & 3.75 & 61.11 & 18.23 \\
\hline SYPS & 0.23 & 0.13 & 31.51 & 17.81 & 56.52 & 76.49 \\
\hline
\end{tabular}

Table 3. Phenotypic correlation coefficients among yield and yield contributing characters in onion.

\begin{tabular}{|c|c|c|c|c|c|c|c|c|c|c|c|c|}
\hline Characters & NLMFS & NPMFS & FPH & $\mathrm{FSH}$ & NFPS & SD & NSPP & NSPS & FWB & $\mathrm{BL}$ & $\mathrm{BD}$ & SYPS \\
\hline$\overline{\mathrm{DFI}}$ & 0.479 & 0.133 & 0.098 & $-0.737^{\star *}$ & 0.0508 & -0.199 & -0.036 & 0.032 & 0.158 & -0.128 & $-0.538^{*}$ & -0.344 \\
\hline NLMFS & & $0.878^{* *}$ & 0.324 & -0.367 & -0.454 & 0.174 & -0.020 & 0.196 & 0.347 & 0.265 & -0.038 & 0.285 \\
\hline NPMFS & & & 0.216 & -0.133 & -0.406 & -0.080 & 0.272 & 0.197 & -0.061 & -0.070 & -0.231 & $0.533^{*}$ \\
\hline FPH & & & & -0.076 & 0.377 & 0.024 & $0.550^{*}$ & 0.470 & 0.388 & 0.148 & 0.362 & $0.555^{*}$ \\
\hline FSH & & & & & $0.587^{*}$ & -0.171 & 0.186 & 0.509 & -0.047 & 0.162 & 0.159 & $0.596^{*}$ \\
\hline NFPS & & & & & & -0.453 & 0.472 & $0.781^{* *}$ & 0.068 & -0.043 & 0.136 & 0.422 \\
\hline SD & & & & & & & $-0.726^{\star *}$ & $-0.706^{* *}$ & $0.709^{* *}$ & $0.822^{* *}$ & $0.764^{* *}$ & -0.350 \\
\hline NSPP & & & & & & & & $0.801^{* *}$ & -0.441 & $-0.615^{\star}$ & -0.406 & $0.686^{* *}$ \\
\hline NSPS & & & & & & & & & -0.147 & -0.277 & 0.156 & $0.782^{* *}$ \\
\hline FWB & & & & & & & & & & $0.923^{\star *}$ & $0.700^{* *}$ & $-0.540^{*}$ \\
\hline $\mathrm{BL}$ & & & & & & & & & & & $0.813^{* *}$ & -0.067 \\
\hline $\mathrm{BD}$ & & & & & & & & & & & & 0.170 \\
\hline
\end{tabular}

* indicates significant at $5 \%$ level of probability, ${ }^{* *}$ indicates significant at $1 \%$ level of probability. 
Correlation coefficients revealed that $\mathrm{BL}, \mathrm{BD}$ and $\mathrm{SD}$ are important as they exhibited significant positive correlation with FWB, which indicated that increase of the values of these characters will increase FWB. Again, number of NSPP, NSPP, FSH, FPH and NPMFS also exhibited positive correlation with SYPS suggesting increase of these traits would increase seed SYPS. Among these traits, BL, FWB, FSH, NSPS and FPH had high genotypic coefficients of variations and high heritability coupled with high genetic advance as percentage of mean which suggested that selection based on these characters would give better response for improving bulb yield as well as seed yield in onion.

\section{References}

Al-Jiboui H A, Miller P A and Robinson H F (1958) Genotypic and environmental variation and covariances in an upland cotton cross of interspecific origin. Agron. J. 50: 633-639.

Burton G W (1952) Quantitative inheritance in Grasses. Proc. 66 Intl. Grassld. Congr. 1: 277-283.

Burton G W and de Vane E H (1953) Estimating heritability it tall feseue from replicated clonal material. Agron. J. 45: 478-481.

Comstock R E and Robinson H F (1952) Genetic parameters, their estimate and significance. Proc. $6^{\text {th }}$ Intl. Grassld. Congr. 1: 284-291.

Hanson G, Robinson H F and Comstock R E (1956) Biometrical studies on yield in segregating population of Korean Lespedeza. Agron. J. 48: 268-274.

Johnson H W, Robinson H F and Comstock R E (1955) Estimates of genetic and environmental variability in soybean. Agron. J. 47: 314-318.

Hossain A K M A and Islam J (1994) Status of Allium production in Bangladesh. Acta. Hort. 358: 33-36.

Nadkarni K M (1927) Indian Material Media. Nadkarni and Co., Bombay.

Sandhu J S and Korla B N (1976) Variability, heritability and correlation study in onion. Indian J. Hort. 32: 71.

Sharfuddin A F M and Siddique M A (1985) Sabji bighan (1st edn.), BAU, Mymensingh. pp: 1-9. 